\title{
Editorial: A Certain Laxity
}

In 1832 J.S.Mill wrote that 'a certain laxity in the use of language must be borne with, if a writer makes himself understood'. At first sight, this statement might seem unexceptionable. Here we have the writer thinking not to inconvenience the reader, even to be agree$a b l e$, so as to ensure that the message gets across. It is a matter of politeness, to speak plainly, and if clarity is not enough (to echo the title of a famous book of the 1960s), clarity is certainly essential, it would be said, and, up to a point, said reasonably.

But maybe, to go a little deeper, there is in Mill's pronouncement not just an element of condescension (the poor reader, uneducated or unintelligent, as the case may be, cannot approach the intellectual and moral rigour of the writer!), but there is also a fatal dissociation of message and expression. What are these messages, which can be expressed indifferently, with or without laxity? The writer who indulges his or her reader (or is it him or herself?) in laxity begins to look like the bureaucrat who has to explain some mind-numbing policy to an unwilling populace, the advertiser who is trying to sell an indifferent product to a half-somnolent audience, the politician or journalist who, in speaking what he or she imagines to be the language of the people, coarsens both him or herself - and what he or she has to say.

Did Mill allow himself 'a certain laxity' in expounding his version of utilitarianism or in explaining the difference between cases where the state might be permitted to constrain individual liberty and those where it might not? Or is the laxity he certainly allows himself at crucial points in his arguments a sign of what was ultimately, if not paradoxically, a fundamental lack of clarity in his own mind, and over which commentators have argued and pondered ever since?

Difficulty and complexity of thought do not permit the wilful obscurity and oracularity we find in some of our contemporaries or, what we find in others of them, jargon-ridden, symbolically-laden density far from any reasonable dialect of English. Both can in their own ways be evasions of real thinking, just as much as an easy-going laxity; but it is impossible to imagine Descartes or Hume or Wittgenstein allowing themselves laxity of expression. For them, what counted was the thought. That and its expression were inseparable; the two drove each other, and one could not be trimmed to the demands of the other. 


\section{Editorial}

Forty or so years after Mill was bravely bearing a degree of laxity in his writing, Ruskin said this: 'Be sure also, if the author is worth anything, that you will not get at his meaning all at once ... not that he does not say what he means, and in strong words too; but he cannot say it all; and what is more strange, will not ... (there is) a cruel reticence in the breasts of wise men which makes them always hide their deeper thought. They do not give it you by way of help, but of reward; and will make themselves sure that you deserve it before they allow you to reach it.'

Which is really kinder to the reader, the 'cruel' reticence which makes the reader grapple with the thought in order to grasp it, or the 'certain laxity' would-be popularisers of philosophy (and not only popularisers) may be disposed to allow themselves? Our answer to this question in any actual case will doubtless depend on whether the author in question is actually worth anything. 